\title{
Oral Lecithin and Linoleic Acid in Friedreich's Ataxia: I. Design of the Study, Material and Methods
}

\author{
S.B. MELANCON, L. DALlaiRE, M. POTIER, M. VANASSE, P. MAROIS, G. GEOFFROY, A. BARBEAU
}

\begin{abstract}
SUMMARY: $A$ clinical and biochemical evaluation of twenty-two patients with Friedreich's Ataxia and ten normal controls was undertaken in 1980 to assess the effect of lecithin and linoleic acid supplements on the course of the disease. The trial consisted of two consecutive six months periods on either supplements in a double-blind crossover fashion. Clinical appraisal was performed with regards to the following parameters: joints mobility, muscle strength, equilibrium, coordination, motor accuracy, speech and numerous day to day activities. Blood samples were $o b$ tained at the beginning and in the course of the trial for enzymatic determinations. This paper describes the methodology of the study.
\end{abstract}

RÉSUMÉ: Vingt-deux patients atteints d'Ataxie de Friedreich et dix témoins normaux ont participé à une étude d'un an visant $\dot{a}$ évaluer les effets cliniques et biochimiques d'un supplément oral de lécithine ou d'acide linoléique. Diverses fonctions cliniques, tel l'amplitude articulaire, la musculature, l'équilibre, la coordination, la précision motrice, le langage et la réalisation des activités journalières, ont été mesurées. Des prélèvements sanguins ont été effectués au début et pendant l'étude pour fin de dosages biochimiques. Le texte qui suit décrit l'essentiel de la méthodologie utilisée.

Le centre de recherche pédiatrique, Hôpital SainteJustine, Université de Montréal.

Reprint requests for the entire supplement on Friedreich's Ataxia (Phase Three, Part Two) to: Prof. André Barbeau, Clinical Research Institute of Montreal, 110 West Pine Avenue, Montreal, Quebec, Canada H2W 1R7.

\section{INTRODUCTION}

Conflicting impressions of clinical improvement with the use of oral choline chloride or phosphatidylcholine (lecithin) supplements in patients with Friedreich's ataxia have been reported by different authors (Barbeau 1978a, 1978b; Legg, 1978; Philcox and Kies, 1979; Legg, 1979; Chamberlain et al 1980; Melançon et al 1980). In the first controlled study to be published; Livingstone et al (1981) reported mild but significant improvement in upper limb coordination in three of seven patients with Friedreich's ataxia after six weeks of oral choline chloride at doses of six or twelve grams a day. More recently, Pentland et al, (1981) were unable to show any beneficial response to lecithin $(25 \mathrm{~g}$ of pure lecithin per month for two four-week periods) in twelve patients with Friedreich's ataxia.

The present study was initiated in early 1980 at the request of the Quebec Cooperative Study Group. The objectives were (1) to assess methods of clinical evaluation for field testing the progression of the disease, (2) to provide a mean of correlating the patient's personal feeling of improvement with objective clinical measurements during the course of a therapeutic trial with lecithin and (3) to confirm previously reported biochemical changes in serum lipoamide dehydrogenase activity brought about by lecithin supplements. The musculoskeletal deformations, the muscle weakness, the after-effects of spinocerebellar and posterior column degeneration and the functional losses were among the clinical manifestations of Friedreich's ataxia, those which more readily lent themselves to evalua- tion by quantitative methods. Serum lipoamide dehydrogenase activity was selected among other biochemical parameters because of its close relationship with the pyruvate dehydrogenase enzyme complex which has been shown to be abnormal in some patients with Friedreich's ataxia (Barbeau et al 1976; Blass et al 1976; Filla et al 1978).

The rationale for using lecithin in this study has emerged from both animal and clinical experiments which will not be reviewed here (see Barbeau, 1979). The choice of a linoleic acid-rich preparation as an alternative to lecithine during the course of this study was pure coincidence.

The composition of what was presented to the investigators as a placebo capsule by the manufacturing company was disclosed at the end of the study only and proved to be a preparation of safflower oil which contains close to ninety percent linoleic acid. Thus the present study turned out to be a double-blind crossover trial of lecithin versus linoleic acid rather than lecithin versus placebo.

\section{PATIENTS}

Twenty-two patients and twelve controls participated in the study. They were divided between two groups according to age and place of residence, making sure that siblings would be in the same group and receive the same supplement at the same time. Group A included eleven patients (age 9 to 23 years; mean, 16.3) and six controls (age 13 to 38 years; mean, 20.2). Group B was composed of eleven patients (age 8 to 23 years; mean, 16.5) and six controls (age 15 to 39 years; mean, 23.6). The patients male: female 
ratio was $7: 4$ in group $A$ and $6: 5$ in group B. All patients were assessed as having "typical Friedreich's ataxia" according to the clinical criteria suggested by us (Geoffroy et al 1976). Functional staging (table I) of the severity of the disease was evaluated at the beginning of the study according to Pourcher and Barbeau (1980). It was not possible to distribute patients evenly between both groups according to stage: group $\mathrm{A}$; stage II, 6 ; stage III, 4; stage IV, 1: group $\mathrm{B}$; stage I, 2; stage II, 5: stage III, 4.

\section{ORAL SUPPLEMENTS}

The trial consisted of two consecutive six-month periods during which patients and controls received lecithin or safflower oil, in the form of capsules containing 1.2 gram of either supplement, at a daily dose of 0.2 gram per kilogram of body weight, divided equally every eight hours if possible (the composition of the capsules is detailed in table II). Since many patients and controls were within the school-age group, it was felt unnecessary to awake them at night and the last daily dose was taken before going to bed.

The maximum daily dose allowed was twelve grams or ten capsules. Three months before entering the trial, all patients were advised not to take any medication or supplement without the consent of the project director. During the course of the trial, all medication or drugs prescribed for medical reasons such as, temperature, malaise, infections, etc. were also reported to the investigators. Group A patients and controls were started on lecithin supplements for the first sixmonth period and switched to safflower oil for the last six-month period. Group $B$ went the other way around.

\section{METHODS OF CLINICAL APPRAISAL}

\section{a) joint mobility and musculoskeletal deformities}

The evaluation of joint mobility was done by the same two experienced persons, one physiotherapist (Louise Barabé), the other ergotherapist (Alain Proulx) at the beginning of the trial and at six-month intervals thereafter. The

\begin{tabular}{|c|c|c|c|c|c|c|c|}
\hline & & $\begin{array}{c}G R O \\
A T I E \\
A T \\
F U N C \\
B E G\end{array}$ & $\begin{array}{l}\text { TA } \\
\text { P DIST } \\
T S W I \\
\text { YIA BY } \\
\text { TIONA } \\
\text { VNING }\end{array}$ & $\begin{array}{l}\text { I } \\
U T I O N \\
R I E D R E \\
\text { RIEEX } \\
\text { AGE AT } \\
T H E S T L\end{array}$ & & & \\
\hline & GROI & & & & GRO & & \\
\hline Name & Sex & Age & Stage & Name & Sex & Age & Stage \\
\hline DDj & $\mathbf{M}$ & 9 & II & $\operatorname{Mcc}(3)$ & $F$ & 8 & I \\
\hline $\mathrm{MC}$ & $\mathrm{F}$ & 12 & II & $\mathrm{HL}$ & $\mathbf{M}$ & 14 & II \\
\hline StJ (1) & $\mathbf{M}$ & 13 & II & $\mathrm{MM}$ & $\mathbf{M}$ & 14 & III \\
\hline LT & $\mathbf{M}$ & 14 & II & FJ & $\mathbf{M}$ & 15 & II \\
\hline SyJ (1) & $\mathbf{M}$ & 15 & III & GC (3) & $\mathbf{M}$ & 15 & II \\
\hline MD & $\mathrm{F}$ & 16 & III & LB & $\mathrm{F}$ & 16 & II \\
\hline SP & $\mathrm{F}$ & 17 & IV & MG (4) & $\mathbf{M}$ & 17 & I \\
\hline DL (2) & $\mathbf{M}$ & 19 & II & SG (4) & M & 19 & II \\
\hline $\mathrm{CY}$ & $\mathbf{M}$ & 19 & II & $\mathrm{CD}(5)$ & $\mathrm{F}$ & 19 & III \\
\hline GL (2) & $\mathbf{M}$ & 22 & III & $\mathrm{DDu}$ & F & 22 & III \\
\hline DT & $\mathrm{F}$ & 23 & III & $\mathrm{DD}(5)$ & $\mathrm{F}$ & 23 & III \\
\hline
\end{tabular}

* numbers in parenthesis match siblings

following articulations were assessed; shoulder (flexion, int. rotation, ext. rotation), hip (extension, int. rotation, ext. rotation), ankle (dorsal, flexion, eversion, inversion), toes (flexion, int. rotation, ext. rotation). Scores of degrees of amplitude gained or lost were recorded for both left and right sides and new deformations noted.

\section{b) muscle function}

Few studies have reported a detailed appraisal of the muscle weaknesses in patients with Friedreich's ataxia (see Richards et al, 1980). Authors agree on the predominance of weaknesses in the lower extremities rather than the upper extremities, in the flexor muscles rather than the extensor muscles and in the distal more than the proximal muscles. Two methods of muscle evaluation were used. The first one is semiquantitative and relies on the experience of the physiotherapist. The following fifty muscle groups were assessed using a scoring system of 0 to 5 and standardized positioning techniques (Kendal et al, 1974), neck (flexor, extensor), shoulder (abductor, adductor, ext. rotation, elevation), elbow (flexor, extensor), wrist (flexor, extensor), hand (apposi- tion, dorsal interosseous), trunk (dorsal, abdominal), hip (flexor, extensor, abductor, adductor), knee (flexor, extensor), ankle (flexor, extensor, abductor, adductor), foot (common flexor and extensor). The maximum normal score was 250 . Results were expressed in percent gain or loss over the pretreatment score.

\begin{tabular}{lcc}
\hline \multicolumn{3}{c}{ TABLE II } \\
MEDIUM-CHAIN FATTY ACID \\
COMPOSITION OF THE \\
LECITHIN A ND SAFFLOWER OIL \\
SUPPLEMENTS USED IN THE \\
\multicolumn{3}{c}{ TRIAL } \\
\hline Fatty & \multicolumn{1}{c}{ Safflower } \\
Acids & Lecithin* & Oil** \\
$16: 0$ & $0.87 \%$ & $0.18 \%$ \\
$16: 0$ & $13.50 \%$ & $4.99 \%$ \\
$16: 1$ & $0.18 \%$ & $0.05 \%$ \\
$18: 0$ & $2.09 \%$ & $0.57 \%$ \\
$18: 1$ & $12.13 \%$ & $7.14 \%$ \\
$18: 2$ & $59.77 \%$ & $86.77 \%$ \\
$18: 3$ & $11.47 \%$ & $0.30 \%$ \\
\hline & \\
\hline * From Lalco Ltee; Montréal and ** & L \\
R.P. Scherer (Canada), Walkerville, \\
Ontario.
\end{tabular}


The second method was an innovation in our hands as it involved the use of dynamometers. The instruments used were two chatillon DPP dynamometers with $5 \mathrm{~kg}$ and $25 \mathrm{~kg}$ dial pushpull gauges respectively. The following muscle functions were studied: flexion of the neck, abduction of the shoulders, adduction of the fifth finger, palmar interosseous (second finger), extension of the second finger, abduction of the hip, extension of the knee, dorsiflexion and eversion of the foot. In our protocol, standardized positions were defined for both patient and examiner. Three readings were obtained for each muscle function but the median only was retained. Results were expressed in percent gain or loss over the antetreatment values. A detailed description of the procedure will be published elsewhere.

\section{c) Ataxia, coordination and motor ac- curacy}

In order to evaluate the after-effects of the disease upon gait and motor activities, these tests were administered to patients before and at the end of each trial period.

\section{LOWER EXTREMITIES}

1) steadiness of gait; walking patients had to travel a minimum distance of twenty feet inside each of six different corridors. Corridor number one was a single line (tightrope walk). The other corridors were respectively $20,30,50,75$ and 100 centimeters in width. Each patient was allowed one trial per corridor and the best performance only was recorded.

2) tests with meter; A specially designed board with a pedal fitting over a manual cell counter fingerboard was used to measure coordination and speed. The number of successful triggers was recorded during 15 seconds for the foot, 30 seconds for the knee and 30 seconds for the hip. Results were expressed in percent gain or loss.

3) timed stability; Patients were asked to stand on one or two feet, eyes open or closed for up to 60 seconds and their score recorded in seconds. Results were expressed in percent gain or loss.

\section{UPPER EXTREMITIES}

1) motor accuracy was evaluated with the use of the Southern California Sensory Integration Tests (SCSIT).

2) tests with meter; Using the specially designed board, patients were instructed to press the trigger with their index, repeatedly for 15 seconds (repetitive movements), then to press two triggers in turn (distal and proximal coordination) during 30 seconds. The meter-nose test was also given as a measure of accuracy and speed ( 30 seconds).

\section{d) Functional tests}

The objectives of these tests were to assess current day-to-day activities and to obtain data which could be used in correlation with the result of a questionnaire filled by the patient himself, regarding the same activities.

1) timed functional tests; these tests were administered only to ambulatory patients; running a thirty feet dash, climbing eight stairs with or without handrail, getting up from a sitting stance on the floor. These tests were given to all patients: to put on and take off a t-shirt, to tie up a shoe, to read the names of the provinces of Canada.

2) untimed functional tests: These tests were scored as follows; 0 , if patient is unable to perform; 1 , if patient succeeds with minimal help from examiner; 2 , if patient succeeds all by himself; patient supine, raises head, turns around on both sides, sits up; patient stands up from a seat; patient walks; patient stands on right, left leg; patient jogs on left, right foot. The maximum score is twenty. Results were expressed in percent gain or loss over pre-treatment values.

\section{e) Questionnaire}

The questionnaire consisted of sections with different statements pertaining to the actual situation of the patient with regards to (1) locomotion and transfer, (2) alimentation, (3) hygiene, (4) clothing, (5) speech and (6) writing. A total of 100 points could be achieved by normal individuals since each of the twenty statements were worth five points. Results of the questionnaire were expressed in percent gain and loss and in number of patients improved or worsened. A copy of the questionnaire is available upon request.

\section{BIOCHEMICAL METHODS}

Blood for enzymatic determination was taken before, three months, six months and twelve months after the beginning of the trial. One $\mathrm{ml}$, aliquots of serum were frozen at $-80^{\circ} \mathrm{C}$ and assayed within a month for lipoamide dehydrogenase activity and kinetic studies according to previously described methods (Melançon et al. 1978 and 1980). Enzymatic activity values were reported in optical density units (O.D.). Conversion to units per liter of serum can be achieved by multiplying O.D. readings by $322 \times 10^{3}$.

\section{ACKNOWLEDGEMENTS}

This project was supponted by grants from l'Association Canadienne de l'Ataxie de Friedreich and the Canadian Muscular Dystrophy Foundation. We are indebted to a large number of contributing persons for making this project possible; Solange Lebrun St-Jacques, Gisèle Fontaine, Louise Barabé, Yvon Proulx, Maurice Duhaime, Paul Allard, Elizabeth Ledru, Bernard Grignon, Ginette Préfontaine, Sylvie Beaulieu, Carl Auger, Colette Courtemanche Lemieux and Jean Davignon.

\section{REFERENCES}

BARBEAU, A., BUTTERWORTH, R.F., NGO, T., BRETON, G., MELANÇON, S., SHAPCOTT, D., GEOFFROY, G., and LEMIEUX, B. (1976) Pyruvate metabolism in Friedreich's ataxia, Canad. J. neurol. Sci., 3: 379-388.

BARBEAU, A. (1978a) Emerging treatments Replacement therapy with choline or lecithin in neurological diseases, Cand. J. Neurol. Sci., 5: 157-160.

BARBEAU, A. (1978b) Lecithin in neurologic disorders. N. Engl. J. Med., 299: 200-201.

BARBEAU, A. (1979) Lecithin in movement disorders. In: Barbeau, A., Growdon, J.H., Wurtman, R.J., eds. Nutrition and the brain. Vol. 5, New York: Raven Press, 263-271.

BLASS, J.P., KARK, R.A.P., MENON, N.K., and HARRIS, S.E. (1976) Low activities of pyruvate and oxoglutarate dehydrogenase complex in five patients with Friedreich's ataxia. N. Engl. J. Med., 295: 62-67.

CHAMBERLAIN, S., ROBINSON, N., WALKER, J., SMITH, C., BENTON, S., KENNARD, C., SWASH, M., KILKENNY, B. and BRANDBURY, S. (1980) Effect of lecithin on Disability and plasma freecholine levels in Friedreich's Ataxia. J. Neurol. Neurosurg. Psychiatry, 43: 843845. 
FILLA, A., BUTTERWORTH, R.F., GEOFFROY, G., LEMIEUX, B. and BARBEAU, A. (1978) Serum and platelet lipoamide dehydrogenase in Friedreich's ataxia. Can. J. Neurol. Sci. 5: 111-114.

GEOFFROY, G., BARBEAU, A., BRETON, G., LEMIEUX, B., AUBE, M., LEGER, C. and BOUCHARD, J.P. (1976) Clinical description and roentgenologic evaluation of patients with Friedreich's ataxia. Canad. J. Neurol. Sci., 3: 279-286.

KENDALL, H.D., KENDAL, F.P. and WADSWORTH, G.E. (1974). Les muscles. Bilan et étude fonctionnelle. Ed. S, A. Maloine, Paris, France.

LEGG, N.J. (1978) Oral choline in cerebellar ataxia, Brit. Med. J., ii: 1403.
LEGG, N.J. (1979) Oral choline in cerebellar ataxia, Brit. Med. J., ii: 133.

LIVINGSTONE, I.R., MASTAGLIA, F.L., PENNINGTON, R.J.T. and SKILBECK, C. (1981) Choline chloride in the treatment of cerebellar and spino-cerebellar ataxia. J. Neurol. Sci. 50: 161-174.

MELANÇON, S.B., DALLAIRE, L. and POTIER, M. (1978) Lipoamide dehydrogenase in cultured human skin fibroblasts. Clin. Chim. Acta. 87: 29-34.

MELANCON, S.B., FONTAINE, G., GEOFFROY, G., VANASSE, M., DALLAIRE, L. and POTIER, M. (1980) Correlation between serum lipoamide dehydrogenase activity and phosphatidylcholine therapy in
Friedreich's ataxia. Can. J. Neurol. Sci. 7: 413-416.

PENTLAND, B., MARTYN, C.N., STEER, C.R. and CHRISTIE, J.E. (1981) Lecithin in Friedreich's ataxia. Br. Med. J. 282: 1197-1198.

PHILCOX, D.V. and KIES, B. (1979) Choline in hereditary ataxia. Brit. Med. J., ii: 613.

POURCHER, E. and BARBEAU, A. (1980) Field testing of an ataxia scoring and staging system. Can. J. Neurol. Sci. 7: 339-344.

RICHARDS, C., BOUCHARD, J.P., BOUCHARD, R. and BARBEAU, A. (1980) A preliminary study of dynamic muscle function in hereditary ataxias. Can. J. Neurol. Sci. 7: 367-378. 